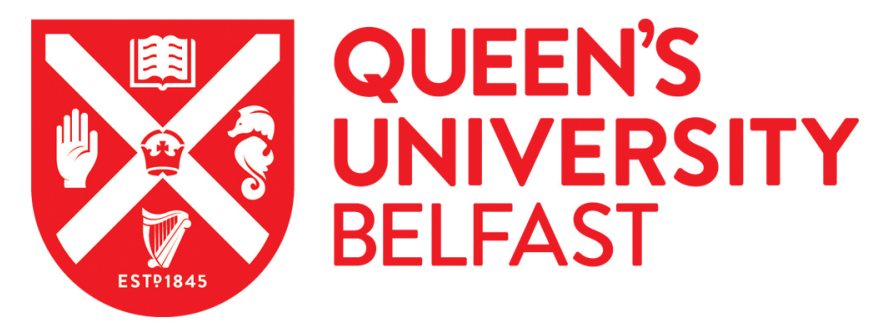

\title{
The donor-beneficiary charity accountability paradox: a tale of two stakeholders
}

Connolly, C., \& Hyndman, N. (2017). The donor-beneficiary charity accountability paradox: a tale of two stakeholders. Public Money and Management, 37(3), 157-164. https://doi.org/10.1080/09540962.2017.1281629

Published in:

Public Money and Management

Document Version:

Peer reviewed version

Queen's University Belfast - Research Portal:

Link to publication record in Queen's University Belfast Research Portal

Publisher rights

Copyright 2017 Taylor \& Francis.

This work is made available online in accordance with the publisher's policies. Please refer to any applicable terms of use of the publisher.

\section{General rights}

Copyright for the publications made accessible via the Queen's University Belfast Research Portal is retained by the author(s) and / or other copyright owners and it is a condition of accessing these publications that users recognise and abide by the legal requirements associated with these rights.

Take down policy

The Research Portal is Queen's institutional repository that provides access to Queen's research output. Every effort has been made to ensure that content in the Research Portal does not infringe any person's rights, or applicable UK laws. If you discover content in the Research Portal that you believe breaches copyright or violates any law, please contact openaccess@qub.ac.uk. 
Public Money \& Management Accepted Article Pre-publication

The donor-beneficiary charity accountability paradox: a tale of two stakeholders Ciaran Connolly and Noel Hyndman (Queen's University Belfast) 


\title{
The donor-beneficiary charity accountability paradox: a tale of two stakeholders
}

\section{Ciaran Connolly and Noel Hyndman (Queen's University Belfast)}

\begin{abstract}
Using stakeholder theory, this article explores the motivations of charities in discharging accountability and the interplay of donor and beneficiary accountability needs. In particular, it considers the extent to which concentration on one group may disadvantage another, something suggested by theory. This research finds that stakeholders commonly perceived as more salient, such as donors, cede power and impute saliency to beneficiaries.
\end{abstract}

Ciaran Connolly is professor of accounting and subject leader in Accounting at Queen's Management School, Queen's University Belfast. Noel Hyndman is professor of management accounting and director of the Centre for Not-for-profit and Public-sector Research at Queen's Management School, Queen's University Belfast; he has been a member of the UK Charity Commission SORP Committee since 2006. The authors would also like to thank the Certified Accountants Educational Trust for their financial and research support of this project. 


\title{
Introduction
}

\author{
'It was the best of times, \\ It was the worst of times.' \\ A Tale of Two Cities \\ Charles Dickens
}

The UK-based Charity Commission (2004) interprets accountability mainly in terms of providing information to stakeholders that is impartial, comparable, understandable and focused on stakeholders' needs. Given the sizeable funds provided to charities, combined with highly publicized scandals, the extent to which charities are accountable for how they spend this money has received considerable attention, with the need for transparency being widely articulated (Ebrahim, 2003a; Cordery and Baskerville; 2011; Ipsos Mori, 2012). The Charity Commission in England and Wales has been charged with enhancing charitable accountability, increasing public trust and promoting the effective use of charitable funds. In Scotland and Northern Ireland, recent regulatory changes have emphasized similar themes.

Mitchell et al. (1997) assert that the degree to which particular stakeholders' accountability needs are prioritized depends on their 'salience', which is determined by their power, legitimacy and urgency. Developed in a corporate context, stakeholder salience suggests that stakeholders compete for attention, with greater attention to one resulting in less attention to another. Such a framework has application for charities, with key external stakeholders including beneficiaries and donors. Indeed, while meeting beneficiary interests is central to a charity's mission, donors, as providers of funds, are powerful stakeholders.

This article considers whether concentrating on one stakeholder group may disadvantage another. In particular, it explores the motivations of charities in discharging accountability and the interplay of donor and beneficiary accountability needs. Key questions considered are: to whom is a charity accountable? and does a donor focus conflict with a beneficiary focus? While in a corporate context, focusing on discharging accountability to finance providers may be detrimental to other stakeholders, there is arguably less likelihood of this occurring in the charity sector because donors' (providers of finance) interests may (or perhaps should) be closely aligned with those of beneficiaries. Notwithstanding this expectation, in various settings the potential for mission drift has been recognized, whereby, responding to the promptings of particularly influential or powerful stakeholders (or failing to focus on key aims), the charity can move away from its key mission (which is often linked to beneficiary focus) - see Bruce and Chew (2011), Considine et al. (2014) and Ebrahim et al. (2014). In this article, using empirical interview data, it is argued that stakeholders commonly perceived as salient (donors) cede power and credit saliency to beneficiaries to support their accountability needs. Thus, echoing the sentiments of some of the most famous opening lines of an English novel that introduce this section (lines from $A$ Tale of Two Cities), a potential stakeholder paradox is recognized.

In terms of format, the next section reviews relevant accountability and stakeholder salience literature in order to consider how charity accountability might be constructed and discharged; this is used as a basis for interpreting the empirical work presented later. Then, the research method employed is outlined and the results presented. Finally, the results are discussed and conclusions drawn.

\section{Accountability and stakeholders}

What is charity accountability?

Traditionally, accountability has been viewed from a reporting perspective whereby organizations, acting as agents, accounted to their principals (Laughlin, 1990; Ebrahim, 2003a). Accountability here is an externally motivated paradigm where principals oversee and control the agents' activities and the latter seek to meet the standards of behaviour prescribed by the principals (Fry, 
1995). Previous research has also considered accountability in the context of stakeholder theory (Hyndman and McMahon, 2011; Dhanani and Connolly, 2012), with a stakeholder being defined as a group or individual who can affect or is affected by the achievement of the organization's objectives (Freeman, 2010). Here, the central argument is that if organizations openly engage with stakeholders, they will build legitimacy and reputation that will result in competitive advantage. This suggests that organizational survival and success require stakeholder support, and that management needs to legitimize organizational activities by demonstrating the organization's values, beliefs and successes (Samkin and Schneider, 2010). Additionally, accountability has been examined in terms of the role and value of different accountability mechanisms (O'Dwyer and Unerman, 2007) and how it plays out in organizations (O'Dwyer and Boomsma, 2015), including taking responsibility for actions and behaviours (Ebrahim, 2003a).

\section{To whom and what motivates charity accountability?}

A number of studies have identified different stakeholders to whom a charity should account. These include donors, the accounting profession, regulators, beneficiaries, government and the public (Hyndman and McDonnell, 2009). This array of stakeholders presents charities with complex and often competing needs to meet (Codery and Baskerville, 2011).

Mitchell et al.'s (1997) stakeholder salience theory posits that once stakeholders are identified, organizations rank competing claims, with the most salient stakeholders being those perceived to have power, legitimacy and urgency. Power reflects the extent to which a stakeholder can impose its will on an organization, while urgency is the degree to which stakeholder claims require immediate attention due to their time-sensitivity or criticality. Legitimate stakeholders include those that contract with an organization as well as those with moral legitimacy, such as donors and beneficiaries. Stakeholders perceived as possessing all three attributes are deemed most salient ('definitive stakeholders', Mitchell et al., 1997, p. 878), with their needs likely to be prioritized. Those demonstrating fewer attributes have less salience. In a charity context, 'large' donors are often identified as the most salient because their funding ensures long-term organizational survival (Hyndman, 1990). In contrast, Cordery and Baskerville (2011) assert that while the donating public ('small' donors: donors of relatively small, but often regular, amounts) and beneficiaries may have moral rights/expectations, neither will exhibit high salience as they are bereft of power. Thus, consistent with the positive or managerial branch of stakeholder theory, charities may focus on being accountable to major donors at the expense of other stakeholders (raising the potential for mission drift). Although, as argued later, meeting these donors' needs may not necessarily be detrimental to other stakeholders, including beneficiaries.

In a business context, Donaldson and Preston (1995) describe two distinct motivations (instrumental and normative) on why organizations do/do not take account of stakeholder needs. Their instrumental view, which echoes Mitchell et al.'s (1997) arguments, contends that businesses prioritize those stakeholders with the greatest economic power and influence to ensure their own success and survival. In comparison, the normative perspective affirms that individuals have a moral duty to consider each other's needs and opinions. Thus, all stakeholders are honoured equitably and participation is promoted. In a nonprofit setting, and contrary to Mitchell et al.'s main thrust, Conforth (2003) argues that power differentials may be inconsequential and management genuinely may want and choose to account to and for its constituents (Lawry, 1995).

Albeit using different terminology, Roberts (1991) and Laughlin (1996) categorize accountability similarly to Donaldson and Preston (1995). Roberts's hierarchical and Laughlin's contractual accountability equate to Donaldson and Preston's instrumental accountability, while their socializing and communal accountability respectively is aligned with normative forms. Instrumental/hierarchical/contractual accountability arguably exists in formal relationships, where action and information demand and supply are defined in enforceable terms. In contrast, 
normative/socializing/communal accountability occurs in less formal relationships, where expectations over conduct and information demand and supply are less defined. If a charity's practices are aligned with the normative model, its actions and discourse (for example, in its formal communications) will be characterized by openness and transparency in a desire to meet the (information) needs of all stakeholders equitably. As organizations often seeking a just society, charities might be expected to orient themselves with the normative model (Ebrahim, 2003a); however, balancing external accountability (for example, to donors) and felt responsibility (for example, to beneficiaries) has the potential to create tension (Fry, 1995).

What are the consequences of upward and downward accountability, and how is such accountability operationalized?

The specific natures of instrumental and normative accountability mean that they may be discharged in different ways, depending on those involved. For example, although reports may be contractually required by 'upward' stakeholders (for example, grantmaking organizations), and feature prominently in the discharge of such accountability, normative accountability is more likely to be provided 'downward' (for example, to beneficiaries) in different forms (Broadbent $e t$ al., 1996). While formal reports (of perhaps a less technical nature than those required for 'upward' accountability) and other communications may play a part in 'downward' accountability, features beyond merely providing information will possibly be most relevant (such as the quality and immediacy of service delivery, and 'voice' in terms of decision making). Charities can gain legitimacy from their upward stakeholders by communicating the financial probity and efficiency with which they operate and the positive impact that they have on those they serve (Ebrahim, 2003b). However, while the discharge of accountability also enables charities to achieve legitimacy from their downward stakeholders, their limited power may encourage some organizations to be less focused on this (Assad and Goddard, 2006); although, the potential for mission drift may depend upon, among other things, the degree to which individual charities are strongly value-driven.

Reinforcing the normative model, 'powerful' donors may make beneficiary interaction a funding condition (O'Dwyer and Unerman, 2010). Yet, Kilby (2006) contends that the effectiveness of downward accountability is not always evident and, while there may be benefits in engaging more closely with beneficiaries, such as more intensive focus on key goals and greater legitimation, this is difficult to achieve (Wellens and Jegers, 2011). For example, beneficiaries, even if easily identified, may not want to engage, or engagement may be challenging because of beneficiary-identification problems (such as in medical research and animal welfare charities) (Connolly and Hyndman, 2013).

In practice, upward and downward accountability may represent end-points on a spectrum of accountability positions. Interestingly, in a corporate context, Goodpaster's (1991) stakeholder analysis contrasts with the instrumental view that privileges shareholders as providers of finance. He advocates a 'multi-fiduciary' stakeholder orientation that considers stakeholders beyond those having economic power and, while managers who pursue this approach may face resistance from those who believe that an instrumental orientation is the only 'legitimate' one for businesses, this Stakeholder Paradox is defended on ethical grounds. In a non-governmental organization context, O'Dwyer and Unerman (2007) explore a similar concept, holistic accountability, involving broader accountabilities, not just upward (to donors) and downward (to beneficiaries), but in multiple directions between different stakeholders. They argue that this is desirable from a practical perspective, as it helps ensure that donors and organizations are aware of the most effective ways to deploy finite funding, and from a moral perspective, as it helps discharge accountability derived from moral responsibilities.

Operationally, there are multiple accountability instruments (Ebrahim, 2003b). While accepting that public discourse instruments are only one means through which accountability is discharged (and that accountability is much wider than accounting, no matter how widely 
'accounting' is defined), public discourse is nevertheless a key mechanism as it enables organizations to communicate with constituents and demonstrate that they are operating responsibly (Samkin and Schneider, 2010). Organizations can use discourse to shape stakeholder perceptions and expectations to ensure that organizational behaviours are (perceived to be) aligned with societal values. Public discourse mechanisms include the annual report (used here, for convenience, to refer to documents which comprise an organization's annual financial statements plus any narrative reports by management - it may, as in the UK, be statutorily required) and other voluntary documents published for stakeholder consumption (for example, a less formal annual review). Supplementary accountability mechanisms (outside of merely the provision of information) include: participation, where organizations engage with (downward) constituents and involve them in decision making; and the adoption of standards and codes of conduct which articulate appropriate and accountable behaviour (Ebrahim, 2003b). In practice, accountability mechanisms operate connectedly. Codes of conduct may, for example, inform attempts to account through discourse, and simultaneously, the (self-imposed) pressures to account through discourse may encourage the adoption of specific standards.

The annual report is often viewed as the principal formal means through which management communicates with (often predominantly upward) stakeholders (Yuthas et al., 2002). It often occupies a prominent position as a statutory document (Gray et al., 2006; Samkin and Schneider, 2010), attracting a degree of authenticity not associated with other such organizational media (Coy et al., 2001). High-quality reports can lead to greater confidence in the organization/sector, and greater confidence can lead to increased legitimacy and funding (Laughlin, 1990; Connolly et al., 2013). Two types of information that are important in discharging accountability are financial information as contained in financial statements and wider performance (often non-financial) information, relating to the goals, objectives, efficiency and effectiveness of the organization. Prior research examining charity accounting and reporting in the UK can be categorized into studies that have investigated: the extent to which charity financial statements comply with accounting recommendations (Bird and Morgan-Jones, 1981; Connolly and Hyndman, 2001); and the disclosure of performance information (Hyndman, 1990; Jetty and Beattie, 2009).

\section{Research method}

This research investigates the motivations of charities in discharging accountability, and, in particular, explores a potential conflict between a focus on donors and a focus on beneficiaries. To operationalize this, a semi-structured interview guide, informed by the theoretical issues and empirical findings discussed above, was developed. Using charity contacts from prior research, individuals from four key stakeholder groups (charity auditors, beneficiaries, donors and managers) were contacted by the researchers, the background to the research explained and an interview requested. Given the difficulties of gaining access to interviewees from each group, the potential sensitivities of the matters being discussed and the researchers' desire for the interviewees to be as candid as possible, each potential interviewee was informed (before agreeing to be interviewed) that the interviews would be reported in a manner where specific statements could not be attributed to particular individuals.

In total, the authors conducted 26 interviews, which ranged from one to two hours, and all interviewees allowed their interviews to be recorded, with notes also being taken. The tapes were transcribed immediately to ensure accuracy and comprehension, and Table I provides an analysis of the interviewees by stakeholder group. Giving each interviewee a unique reference (CA1-6, CB1-8, CD1-6 and CM1-6) allows the reader to identify comments from the same interviewee, while maintaining confidentiality. Each interviewee had substantial knowledge of some aspect of the sector. For example: each of the auditors had been engaged in charity audits for a number of years; six beneficiaries had used the services of more than one charity for at least 15 years (the other two had used the services of one large national charity over a prolonged 
period); of the donors, three were individual donors (CD1, CD3 and CD5), two were grant makers (CD2 and CD4) and one a corporate donor (CD6); and each of the charity managers held a senior position in their respective charity.

\section{Table I: Interviewees}

\begin{tabular}{lc}
\hline Stakeholder group (and reference) & Number interviewed \\
\hline Charity auditor (CA1-6) & 6 \\
Charity beneficiary (CB1-8) & 8 \\
Charity donor (CD1-6) & 6 \\
Charity manager (CM1-6) & $\underline{6}$ \\
& $\underline{\underline{26}}$ \\
\hline
\end{tabular}

\section{The views of key stakeholders}

This section reports the views of key stakeholders concerning the issues related to charity accountability explored previously.

What is charity accountability?

While a broad view was that 'accountability is about keeping people informed' (CB8), most interviewees defined it as demonstrating that monies received had been spent in accordance with the charity's aims and objectives. Charity auditors and managers especially linked accountability with stewardship.

Accountability is stewardship isn't it? Management is entrusted with looking after the assets of the organization. (CA4)

I suspect that people want to know that if they are giving you their money, stewardship is strong and that it's being spent in the way you said you were going to spend it. (CM5)

This was often associated with implementing appropriate systems to record income and expenditure, particularly with respect to restricted funds, and to ensure compliance with the charity Statement of Recommended Practice (SORP) (which contains UK recommendations, or, especially with large charities, requirements, with respect to accounting practice.

Accountability is about ensuring that monies are used for the purposes that the donors had intended. (CM3)

To whom and what motivates charity accountability?

Many interviewees acknowledged that charities are accountable to a variety of stakeholders.

Charities have multiple and overlapping levels of accountability. They're accountable to donors, government, members, beneficiaries and even to the community. (CD2)

The competing demands of beneficiaries and donors dominated responses, although, beneficiaries themselves, while often acknowledging the importance of donors, emphasized their own claims.

The individual in need should be at the centre of everything the charity does. (CB7)

Notwithstanding the beneficiary view on their own position regarding accountability, auditor, donor and manager interviewees tended to deliberate between the primacy of donors and beneficiaries. 
We are given money in trust because of what we do and therefore we are accountable in the first instance to those who give us the money and also to those whom we do work. for. (CM5)

While this might suggest a possible tension between donor and beneficiary needs, most advocated a beneficiary focus.

Obviously you are accountable to the donors as to how you've utilized their money. But if we don't focus on the service user [beneficiary] then we've lost our direction. (CM3)

However, the consensus was that most beneficiaries have little interest in participating in the management or administration of the charity, possibly because of their motivation, capability or the urgency of their needs. Additionally, while beneficiary engagement may potentially improve charity reporting (and sharpen charity actions), and legitimate the accounting and reporting framework, this and other research (for example, Connolly et al., 2013) highlights the difficulties of achieving this. When asked how such engagement could be facilitated, the response was generally that even if encouraged, it was unlikely to happen because beneficiaries were primarily interested in service provision.

The dilemma is that the happier the beneficiaries are with the service, the less likely they are to want to be involved. (CD2)

There is an assumption that beneficiaries want to be involved in decision making, but I suspect an anful lot of them don't. And why should they? All that matters is the service they are getting. (CM6)

Accepting the difficulties of beneficiary engagement, it was suggested that donors 'take a beneficiary-focused position' (CA6). In addition, it was contended that concerns over tensions relating to potentially competing interests between these stakeholders should not be overstated, as meeting beneficiary needs is often synonymous with satisfying those of donors (which are typically related to beneficiary service provision).

It's a conundrum. I don't know if there is a right answer...Probably should be beneficiaries [who are prioritized], but many beneficiaries are unable to articulate their needs or views. Maybe this means charities then focus on their donors. (CA6)

How accountability actually manifests itself depends on who's there to bold charities to account. It might be the regulator because beneficiaries can't. Alternatively, donors can provide a good proxy because they act in the best interests of beneficiaries. (CD4)

Notwithstanding the acknowledged importance of beneficiaries, the vast majority of interviewees accepted that charities try to balance donors' and beneficiaries' interests. However, some, reflecting on current financial pressures in the sector (Charity Finance Group, 2012), or echoing aspects of Donaldson and Preston's (1995) instrumental view, suggested that, despite a moral imperative to focus on beneficiaries, donors could, in certain circumstances, be given primacy.

In theory, charities should be accountable firstly to their beneficiaries... Because of the way things are at the minute in terms of funding, the focus is on donors. (CA2)

What are the consequences of upward and downward accountability and how is such accountability operationalized? 
While beneficiary and small donor interviewees expressed little interest in detailed formal communications, frequently because such documents are perceived as difficult to understand, both groups were adamant that they expected charities to produce such information (for example, a SORP-compliant annual report) as public availability enables scrutiny by others. Beneficiaries particularly expressed a strong preference for regular 'softer' magazines and leaflets containing stories relating to the charity's work.

I know the accounts get done but I'm not that interested. I'd rather read about the members, the services and the different people that have been helped. (CB6)

I like magazines, regular information with personal stories. I even use Facebook. (CB8)

Such views reflect Laughlin's (1996) communal accountability, which suggests that accountability can be less formal where there is trust and little potential for value conflict.

Small donor interviewees expressed limited desire to undertake detailed analyses of formal communications. Referring specifically to the annual report, and perceiving themselves as having limited power and influence, they relied on others to scrutinize such on their behalf (albeit no specifics on who this 'someone else' might be were indicated).

I might thumb through it [annual report], but I'd never look at it in an analytical way. As long as someone else looks to see that they're doing it right, I'm happy with that. (CD1)

While good formal communications were considered necessary, small donors trusted the charities to which they contributed and assumed that others reviewed the information published. Giving decisions were often based upon the 'cause' and reputation of the charity rather than an in-depth analysis of accountability information.

I'm a story person. What prompts me to continue giving is if I think 'Yes, I like what they're doing'. (CD3)

Large donor interviewees confirmed that while formal communications (such as SORPcompliant annual reports) were expected, and were regularly used, they always required additional non-publicly available information and direct engagement before finalising funding (for example, management accounts and cash flow information, coupled with at least one organizational visit). In addition, regular reports (frequently including output information) relating to funded projects were also often required.

Before we go to see the client, we'll have a look at different published reports and the website. But we would never make a decision just on that basis. (CD6)

Interviewees were given the opportunity to indicate what information that is currently not provided should be included in formal communications. Most suggested that more narrative explanations clarifying the story behind the figures would benefit all stakeholders.

Numbers don't tell you what the charity is doing. I like to read the stories of what help people have received. Donors and the public should also want to see what beneficiaries are getting. (CB7)

Many interviewees also believed that greater disclosure of performance information would be a 'good thing' (CB5), with auditor and manager interviewees asserting that further performance information was often available internally than was published externally in the charities they had knowledge of (large charities), and surmised it was also available in smaller charities. 
Most charities will have some measures of how they're performing. It would be problematic if they didn't. Even small charities will have information on the impact of whatever it is they're doing. (CM2)

While many interviewees agreed that performance information was crucial, difficulties in capturing and providing this were acknowledged. These included: finding reliable measures; confidentiality; and freeing staff resources to develop and monitor the measures.

The donor gives you a pound, but can you tell the donor if it was spent effectively, probably not. All you can do is try to assess whether the service has achieved what it is meant to. But often that's a matter of judgement, especially if it's a long-term thing. (CM4)

With respect to 'impact', possibly the ultimate expression of performance, it was generally accepted that while this was vital in the context of accountability, for some charities it might only be measurable in the medium/long term. Charity managers in particular believed that reporting personal stories was a valid means of demonstrating 'impact'.

Stories of how we have helped are one way of illustrating impact, and it can belp you plan your services accordingly. (CM4)

\section{Discussion and conclusions}

Given their public benefit purposes and the advantages of charitable status, accountability should be an intrinsic feature of not only the work that charities do, but also how they report their activities. External stakeholders have information needs, yet, because they normally have limited powers, they must rely primarily on charities to meet these. The actions of charities, together with the provision of financial and performance information (in addition to wider non-financial information), are important to external stakeholders as they make decisions relating to their engagement with, or funding of, the organization. In addition, the provision of information through formal channels, and its (potential for) scrutiny, provides a control on charity management to act in ways that meet stakeholders' needs, especially beneficiaries and donors.

This research considers the motivations of charities in discharging accountability, and explores potential conflicts (particularly between the competing claims of donors and beneficiaries) and the outworking of these. While Goodpaster's (1991) Stakeholder Paradox reflects the competing claims and objectives of different stakeholder groups in a business context, such tensions may not exist to the same extent in a charity setting. Indeed, if charity managers pursue an instrumental approach to the discharge of accountability by focusing on donors' interests, this may, de facto, result in a multi-fiduciary orientation by default (as donors' interests are likely to be aligned with those of beneficiaries). Moreover, if charities embrace a multi-fiduciary approach (and pay particular heed to the needs of beneficiaries), this should not alienate donors (and consequently threaten long-term organizational survival) because of the motives of donors. Managing paradox means embracing and exploring tensions and differences rather than choosing between them. Much of what makes responsible decision making difficult is understanding how there can be an ethical relationship between trustees/management and stakeholders that avoids being too weak (prioritizing donors) or too strong (prioritizing beneficiaries). While, in a corporate context, focusing upon finance providers may be detrimental to other stakeholders, this is perhaps much less likely in charities where there is close alignment between donors' interests and beneficiary needs (notwithstanding the often present danger of mission drift Bruce and Chew, 2011, Considine et al., 2014).

This research finds that accountability is closely associated with demonstrating that monies received have been spent in accordance with the charity's objectives. This in turn is related to the implementation of appropriate systems and controls to record monies received and 
how they are spent in furtherance of these objectives. But how this impacts on charity behaviour, and how it is viewed from, or operationalized at, an individual stakeholder perspective, is unclear. While there was broad agreement that charities are accountable to numerous stakeholders, it is debatable whether donors (who provide funds with no direct economic benefit to themselves) or beneficiaries (who are often central to both donors' funding decisions and the charity's mission) should be at the forefront of charity managers' considerations and the discharge of accountability.

Charities have a fiduciary responsibility to account for the funds received to support their beneficiaries who, while having legitimacy and urgent needs, appear to lack power. In Mitchell et al.'s (1997) parlance, they might be considered 'discretionary' or 'dependent' stakeholders (it would be at charity managers' discretion to respond to their accountability needs, or they would depend on the power of other stakeholders to provide leverage). However, this research finds that stakeholders commonly perceived as more salient, such as large donors (who have power, legitimacy and urgency given their ability to provide or withdraw resources), cede power and impute saliency to beneficiaries. In addition, charity managers, highlighting a 'felt' responsibility, often reflected on the desire to involve, and get feedback from, beneficiaries as a way of giving such individuals voice and sharpening service delivery. Indeed, the possible close alignment between donors' and beneficiaries' interests may result in donors acting as proxies for beneficiaries (especially where beneficiary involvement and feedback is difficult to obtain). This appears at odds with Mitchell et al.'s theory that seems to imply that stakeholders compete for attention. While their general propositions are likely to hold in a business setting where stakeholders largely act for economic reasons (a setting dominated by controlling governance models), they may apply significantly less, or at least in a more nuanced manner, in the charity sector (where 'partnering' models of governance are more likely and certain key stakeholders act for reasons other than economic benefit).

Notwithstanding the above, donors remain vital. Prior research indicates that frequently they are perceived as the most important stakeholder group in terms of accountability, both generally and in the context of formal communications (Hyndman, 1990; Connolly and Hyndman, 2013). This research also affords significant weight to donors. Interviewees (including beneficiaries) recognized that without donors' financial support, charities could not operate. However, donors may not compete with beneficiaries for attention. While mission drift can occur if influential donors/funders lose sight of the mission of the charity (possibly a particular problem with some public sector funding - see Dacombe, 2011), this research suggests it is not generally the case. Often donors go to considerable lengths to support the case of beneficiaries in terms of encouraging their participation in decision making and in focusing on the outputs and impacts that accrue to beneficiaries. Although, paradoxically, while donors may encourage charities to seek more beneficiary engagement in decision making (and charity managers may be supportive of this), and there may be major benefits from such in terms of organizational sharpness, the interviews highlighted major difficulties in achieving this. These include the possibility that beneficiaries, even if they can be easily identified, may not want to engage (especially where service provision meets their needs) or may not have the capacity to engage. 
The research also identifies that if accountability is to be meaningful, it needs to be discharged to different stakeholders in various ways. Since many external stakeholders often rely on formal and informal channels of reporting to meet their information needs, the preparation and publication of such reports to a high standard is viewed by donors (and indeed beneficiaries) as important. Such can demonstrate credibility and legitimacy, ensuring financial discipline and maintaining focus on key performance aims (features that may act in support of beneficiary interest). Although this, and other, research shows that formal reports (such as annual reports) are not particularly engaged with by many stakeholders, often because of their technical, financial emphasis (particularly the case with small donors, and overwhelmingly the case with beneficiaries), they nevertheless enhance upward accountability.

Discharging accountability downwards (to beneficiaries) is more challenging. This research suggests that beneficiaries are predominantly interested in the services that they receive and primarily see accountability in this context. Greater user involvement has been promoted as a means of making organizations more responsive to user needs (Locke et al. 2003), and is viewed as desirable by stakeholders in this research. In addition, such is clearly supported by the Charity Commission (2000) which promotes greater representation of service users (or beneficiaries) on governing boards. Such moves, while potentially sharpening the mission focus of charities and downward accountability to beneficiaries, are difficult to achieve. However, this research suggests that donors are often seen (and frequently see themselves) as proxies for beneficiaries, with the donor regularly taking a beneficiary-focused view. To the extent that donors' can do this, any potential adverse consequences of limited beneficiary involvement may be partially overcome. Thus, donors may act as champions of beneficiaries' interests and reinforce their claims as salient stakeholders. In this respect, paradoxically, contractual motivations may not necessarily be to the detriment of communal accountability as powerful stakeholders exercise their influence on behalf of beneficiaries' interests. Managing this apparent 'paradox' requires key stakeholders, particularly charity managers, to embrace and explore possible tensions and to achieve balance in reporting and in actions.

This research shows a desire by many stakeholders for a more holistic accountability. There is clear evidence that donors (salient stakeholders in the language of Mitchell et al., 1997) promote the claims of beneficiaries (stakeholders who may be less salient). This suggests that beneficiary accountability and interest are often at the heart of the giving decision. Here, the interplay of donor and beneficiary accountability needs and claims may bolster each other. Donors demanding beneficiary focus from a charity can enhance beneficiary accountability; while positive beneficiary experience, and information that such has been achieved, provides donors with assurances of mission achievement. This cycle of reinforcement, which may seem paradoxical in the business context in which stakeholder identification and salience theory was developed, and in which stakeholders often compete with one another for consideration, makes sense in a charity context. In such a scenario, while formal publically-available external reports may be important and, with some stakeholders, be a principal means of discharging accountability, other forms of accountability (such as direct service provision, feedback opportunities and representation) will be critical to beneficiaries. Ideally, the various forms of accountability will align and complement each other.

Despite the desire for a more holistic accountability, this and other research (O'Dwyer and Unerman, 2007; Connolly and Hyndman, 2013) has identified major difficulties (related to lack of resources, organizational commitment, guidance and/or expertize) in achieving meaningful downward accountability even when a stakeholder with seemingly significant power (the primary funder) advocates such. Therefore, well-intentioned desires alone are unlikely to bring meaningful change. Perhaps what is needed is the engagement of agents or 'champions' of change to provide encouragement (or even coercion) and guidance as to what is required. This might involve those concerned with the administration and control of the charity sector or umbrella support organizations (such as, in a UK context, the Charities Aid Foundation, New 
Philanthropy Capital and Intelligent Giving). Without this, moves toward more meaningful holistic accountability will probably be restricted, resulting in a sector afforded limited legitimation.

This article offers critical insights into how charities may react to the accountability needs of various stakeholders. At an individual charity level, it can support improvement in accountability mechanisms, and thus impact and trust. What we see from this research, and what we identify as its main contribution, is the highlighting of the potential for cyclical reinforcing of stakeholder accountability interests; the paradox that as beneficiaries interests are focused upon, donor accountability is strengthened (and vice-versa). In a sector that needs accountability, legitimacy and trust in order to develop and grow, the encouragement of such complementary forces has the capability to provide potency or, in the famous words of Dickens which commenced this article, to provide the best (or at least slightly better) of all times for the charity sector.

\section{References}

Assad, M. and Goddard, A. (2006), Accounting and navigating legitimacy in Tanzanian NGOs. Accounting, Auditing \& Accountability Journal, 19, 3, pp. 377-404.

Bird, P. and Morgan-Jones, P. (1981), Financial Reporting by Charities (Institute of Chartered Accountants in England and Wales).

Broadbent, J., Dietrich, M. and Laughlin, R. (1996), The development of principal agent, contracting and accountability relationships in the public sector: conceptual and cultural problems. Critical Perspectives on Accounting, 7, pp. 259-284.

Bruce, I. and Chew, C. (2011), The marketization of the voluntary sector. Public Money \& Management, 31, 3, pp. 155-157.

Charity Commission (2000), Users on Boards: Beneficiaries who become Trustees (Charity Commission).

Charity Commission (2004), RS8 - Transparency and Accountability (Charity Commission).

Charity Finance Group (2012), Managing Charities in the New Normal - A Perfect Storm? (www.cfg.org.uk).

Connolly, C. and Hyndman, N. (2001), A comparative study on the impact of revised SORP 2 on British and Irish charities. Financial Accountability \& Management, 17, 1, pp. 73-97.

Connolly, C. and Hyndman, N. (2013), Towards charity accountability: narrowing the gap between provision and needs? Public Management Review, 15, 3, pp. 945-968.

Connolly, C., Hyndman, N. and McConville, D. (2013), UK charity accounting: an exercise in widening stakeholder engagement. British Accounting Review, 45, 1, pp. 58-69.

Considine, M., O'Sullivan, S. and Nguyen, P. (2014), Mission drift? The third sector and the pressure to be businesslike: evidence from job services Australia. Third Sector Review, 20, pp. $87-107$

Cordery, C. and Baskerville, R. (2011), Charity transgressions, trust and accountability. Voluntas: International Journal of Voluntary and Nonprofit Organizations, 22, 2, pp. 197-213.

Cornforth, C. (2003), The changing context of governance - emerging issues and paradoxes. In C. Cornforth (ed), The Governance of Public and Non-Profit Organizations: What do boards do? (Routledge).

Coy, D., Fischer, M. and Gordon, T. (2001), Public accountability: a new paradigm for college and university annual reports. Critical Perspectives in Accounting, 12, pp. 1-31.

Dacombe, R. (2011), Can we argue against it? Performance management and state funding of voluntary organizations in the UK. Public Money \& Management, 31, 3, pp. 159-166

Dhanani, A. and Connolly, C. (2012), Discharging not-for-profit accountability: UK charities and public discourse. Accounting, Auditing \& Accountability Journal, 25, 7, pp. 1140-1169.

Donaldson, T. and Preston, L. (1995), The stakeholder theory of the corporation: concepts, evidence and implications. The Academy of Management Review, 20, pp. 65-91. 
Ebrahim, A. (2003a), Accountability in practice: mechanisms for NGOs, World Development, 31 , pp. 813-829.

Ebrahim, A. (2003b), Making sense of accountability: conceptual perspectives for northern and southern nonprofits. Nonprofit Management and Leadership, 14, 2, pp. 191-212.

Ebrahim, A., Battilana, J. and Mair, J. (2014), The governance of social enterprises: mission drift and accountability challenges in hybrid organizations. Research in Organizational Behavior, 34, pp. 81-100.

Freeman, R. (2010), Strategic Management: A Stakeholder Approach (Cambridge University Press).

Fry, R. (1995), Accountability in organizational life: problem or opportunity for nonprofits? Nonprofit Management and Leadership, 6, 2, pp. 181-195.

Goodpaster, K. E. (1991), Business ethics and stakeholder analysis. Business Ethics Quarterly, 1, 1, pp. 53-73.

Gray, R., Bebbington, J. and Collison, D. (2006), NGOs, civil society and accountability: making the people accountable to capital. Accounting, Auditing \& Accountability Journal, 19, 3, pp. 319348.

Hyndman, N. (1990), Charity accounting: an empirical study of the information needs of contributors to UK fundraising charities. Financial Accountability \& Management, 6, 4, pp. 295307.

Hyndman, N. and McMahon, D. (2011), The hand of government in shaping accounting and reporting in the UK charity sector. Public Money \& Management, 31, 3, pp. 167-174.

Hyndman, N. and McDonnell, P. (2009), Governance and charities: an exploration of key themes and the development of a research agenda. Financial Accountability \& Management, 25, 1, pp. 533.

Ipsos Mori (2012), Public Perceptions of Charity - A Report for the Charities Act 2006 Review (Ipsos Mori).

Jetty, J. and Beattie, V. (2009), Charity Reporting - A Study of Disclosure Practices and Policies of UK Charities. Research Report No. 108 (ACCA).

Kilby, P. (2006), Accountability for empowerment: dilemmas facing nongovernmental organizations. World Development, 34, 6, pp. 951-963.

Laughlin, R. (1990), A model of financial accountability and the Church of England. Financial Accountability \& Management, 6, 2, pp. 93-114.

Laughlin, R. (1996), Principals and higher principals: accounting for accountability in the caring profession. In R. Munro and J. Mouritsen (eds), Accountability: Power, Ethos and the Technologies of Managing (International Thomson Business Press).

Lawry, R. (1995), Accountability and nonprofit organizations: an ethical perspective. Nonprofit Management and Leadership, 6, pp. 171-180.

Locke, M., Begum, N. and Robson, P. (2003), Service users and charity governance. In C. Cornforth (ed), The Governance of Public and Non-Profit Organizations: What do boards do? (Routledge).

Mitchell, R., Agle, B. and Wood, D. (1997), Toward a theory of stakeholder identification and salience: defining the principle of who and what really counts. Academy of Management Review, 22, pp. 853-886.

O'Dwyer, B. and Boomsma, R. (2015), The co-construction of NGO accountability: aligning imposed and felt accountability in NGO-funder accountability relationships. Accounting, Auditing \& Accountability Journal, 28, 1, pp. 36-68.

O'Dwyer, B. and Unerman, J. (2007), From functional to social accountability: transforming the accountability relationship between funders and non-governmental development organizations. Accounting, Auditing \& Accountability Journal, 20, 3, pp. 446-471.

O'Dwyer, B. and Unerman, J. (2010), Enhancing the role of accountability in promoting the rights of beneficiaries of development NGOs. Accounting and Business Research, 40, 5, pp. 451471. 
Roberts, J. (1991), The possibilities of accountability. Accounting, Organizations and Society, 16, 4, pp. 355-368.

Samkin, G. and Schneider, A. (2010), Accountability, narrative reporting and legitimation: the case of a New Zealand public benefit entity. Accounting, Auditing \& Accountability Journal, 23, 2, pp. 256-289.

Wellens, L. and Jegers, M. (2011), Beneficiaries' participation in nonprofit organizations: a theory-based approach, Public Money \& Management, 31, 3, pp. 175-182.

Yuthas, K., Rogers R. and Dillard, J. (2002), Communicative action and corporate annual reports. Journal of Business Ethics, 41, pp. 141-157. 